\title{
Disclosure Quality and Dividend Payout in Saudi Firms
}

\author{
Rashidah Abdul Rahman ${ }^{1}$, Eman Saleh Fadel ${ }^{1}$, NajlaAbdul Rahman ${ }^{1}$, Amal Awad ${ }^{1}$ \\ ${ }^{1}$ Faculty of Economics and Administration, King Abdulaziz University, Jeddah, Saudi Arabia \\ Correspondence: Rashidah Abdul Rahman, Faculty of Economics and Administration, King Abdulaziz \\ University, Jeddah, Saudi Arabia.
}

Received: October 15, 2018

Accepted: November 27, 2018 Online Published: December 6, 2018

doi:10.5539/ibr.v12n1p16

URL: https://doi.org/10.5539/ibr.v12n1p16

\begin{abstract}
This study examines how disclosure quality influences the dividend payouts of firms, and provides further evidence concerning the outcome hypothesis and substitution hypothesis. Using a sample of non-financial Saudi Arabian listed firms during 2012-2014, our results provide support for the substitution hypothesis in which outsiders demand higher dividends in a low-quality disclosure environment as a "substitute" for opacity. Further analysis shows that managers pay a higher dividend in an opaque environment not only to establish a reputation among outside capital suppliers but also because they have to disgorge excess cash to circumvent free cash flow problems.
\end{abstract}

Keywords: voluntary disclosure, dividend payout, Saudi Arabia

JEL classification: G35, G34

\section{Introduction}

This paper examines how voluntary disclosure affects dividend payouts. Corporate voluntary disclosure, being in excess of requirements, represents free choice on the part of managers to provide a clear view to stakeholders about the long-term sustainability of the business, and reduces information asymmetry and agency conflicts between managers and investors (Meek et al., 1995; Yuen et al., 2009; Healy \& Palepu, 2001; Boesso \& Kumar, 2007). Poor disclosure quality increases the agency costs as insiders have more opportunities to expropriate outsiders (Lang et al., 2006; DeAngelo et al., 2006). Conversely, high disclosure firms should face lower information asymmetry and be less likely to be undervalued. The information asymmetry hypothesis also suggests that managers could use dividend as a signalling tool to differentiate good quality firms from poor quality firms. By paying dividends, management are no longer capable of using the excess cash for obfuscation and expropriation.

Hence, voluntary disclosure could potentially mitigate the agency problem associated with free cash flow. If managers voluntarily provide investors with timely information about how investment decisions are made and how the resources of firms are spent, investors should be better equipped to evaluate and monitor managerial decisions. As argued by Jensen (1986), the managers of firms with lower disclosure quality are more likely to pay out less dividend to shareholders, spend the free cash flow on empire building and negative net present value projects, and consume perquisites. In contrast, managers find it more difficult to exploit shareholders when disclosure is transparent because shareholders are better able to identify the level of excess cash flow in a transparent disclosure environment and demand higher dividend payouts.

Previous research in developed countries like the US, the UK and Canada, where investor protection is strong, has established a direct positive relationship between disclosure quality and dividend payouts (La Porta et al., 2000, Healy and Palepu, 2001; DeAngelo et al., 2006; Adjaoud and Ben-Amar, 2010). Studies by Kowalewski et al. (2008), Lin, Kuo and Wang (2014) and Lin, Kuo and Wang (2016) have also confirmed that a higher level of corporate governance practices in an environment with greater transparent disclosure would result in higher dividend payouts. In countries where investor protection is strong, insiders find it much more difficult to exploit outsiders when asset values, liabilities, and operating performance are reported in a transparent disclosure environment. However, in countries like Saudi Arabia where investor protection is weak, the question arises concerning how shareholders are guaranteed to receive dividends from firms, given that the legal environment of the country and the governance mechanisms of individual firms offer investors relatively little protection. Studies by Aivazian et al. (2003), and Ramacharran (2001) have shown substantial variations of dividend 
policies across economies, particularly in emerging economies. In this context, the issue of voluntary disclosure and dividend payouts in an emerging economy like Saudi Arabia is worth further investigation.

The voluntary disclosure and dividend payout issue in Saudi Arabia is a unique case to revisit, because, as an emerging market, it differs from the issues of developed countries in many ways. Alzahrani (2013) and Al-Habshan (2015) highlight that Saudi Arabia is an emerging market that has high-growth potential, a relatively weak regulatory environment, weak corporate governance (Institute of International Finance, 2006) and a low level of information disclosure, thereby causing a high information gap between companies and investors. As evidence, Al-Janadi et al. (2013) and Alturki (2014) show that most Saudi firms observe the obligatory reporting requirements but rarely disclose information voluntarily. Instead of paying corporate tax, Saudi firms pay "zakat" (an Islamic tax), which represents 2.5 percent of a firm's unused assets in hand. Hence, Saudi firms are encouraged to distribute almost $100 \%$ of their profits in dividend (Osman \&Mohammed, 2010; Al-Ajmi \& Abo Hussain, 2011). The current study contributes to the existing knowledge concerning the relationship between voluntary disclosure and dividend payout policy, particularly in a developing country like Saudi Arabia that has an opaque disclosure environment and low investor protection policy.

According to La Porta et al. (2000), dividends can be viewed as an "outcome" of an effective corporate governance system or a "substitute" for weak governance. The outcome model is where dividends emanate from a legal protection for minority shareholders and the substitute model is where dividends are a mechanism of market self-regulation that can substitute for weak shareholder protection. In the outcome model, transparent disclosure environments with high investor protection will lead to higher dividend payouts, because shareholders can more accurately measure and use their power to force managers to disgorge cash. However, in countries with poor investor protection, undistributed excess cash is easily appropriated by controlling shareholders for their own private benefit (La Porta et al., 2000, Lang et al., 2006), and thus, investors welcome as much dividends as possible and they assign higher value to such dividends (Pinkowitz et al., 2006 and Kalcheva \& Lins, 2007).In the substitute model, firms pay dividends to establish a good reputation to raise equity in future and predict a higher level of dividend in countries with lower investor protection, where the need for good reputation is strongest. Using international data, the results in the study by La Porta et al. (2000) support the outcome hypothesis over the substitute hypothesis. They document a strong positive relationship between the level of legal protection and the dividend payout. Their findings suggest that investors in countries with better investor protection use their legal power to force companies to pay dividends, and thus prevent them from gaining private benefit from excess cash flows.

Hence, the first objective of our study is to extend and test the outcome and substitution hypothesis argument by examining how disclosure quality in Saudi Arabia affects the dividend payouts of firms. As Saudi Arabia is said to be a relatively low investor protection country, we hypothesise that disclosure quality should be negatively associated with dividend payment. Similar to the substitute hypothesis, we posit that opaque disclosure environments lead to higher payouts because managers have a stronger incentive to establish their reputation for fair treatment.

Mitton (2004) posits that while country-level investor protection is an important factor in preventing expropriation, firm-level corporate governance could carry equal or greater importance as corporate governance practices can vary widely, even among firms in the same country. Accordingly, a similar index of disclosure to that of Gray et al. (1995), and Wang, Sewon \& Claibone (2008) is employed in this study for 122 non-financial Saudi Arabian listed firms during 2012-2014 to examine the impact of voluntary disclosure on dividend payouts. Using a panel regression model over the three-year period, the results in the study provide support for the substitution hypothesis where outsiders demand higher dividends in a low-quality disclosure environment as a "substitute" for opacity. The result contrasts with that found in developed economies that shows a positive relationship between external corporate governance and dividend payout.

The second objective of the study is to further examine how the dividend payout is impacted by the interplay of firm-level disclosure quality and free cash flow (i.e. uncommitted cash flow from operation over and above what is needed to fund current and expected future positive-NPV projects). According to DeAngelo et al. (2006), managers are likely to use free cash flow for their private benefit or to spend the free cash flow on negative net present value investments. Thus, it is argued that distributing dividends to shareholders and reducing the amount of free cash flow will reduce the agency problem between management and minority shareholders. In countries with high investor protection, the outcome model predicts a positive coefficient for the interactive variable between the disclosure quality and free cash flow because firms with a higher cash flow will be forced to pay high dividends. However, in this study, using the substitute model we hypothesise a negative coefficient for the interactive variable because firms in a country with lower investor protection pay dividends through their excess 
cash flow to establish a good reputation among investors. As predicted, our result shows a negative and significant relationship between the interactive variable of disclosure quality and free cash flow with dividend payout. Consistent with the substitution model, Saudi firms pay higher dividends in an opaque environment not only to establish a reputation among outside capital suppliers but also because they have to disgorge excess cash.

This paper proceeds as follows: Section 2 presents a description of the data and empirical methods. Section 3 presents and analyses the results. Section 4 concludes with a summary and recommendations for future research.

\section{Data and Empirical Methods}

\subsection{Data}

The sample consists of unbalanced panel data for 122 non-financial public listed firms in the Saudi Securities Market (Tadawul) for the period between 2012 and 2014, resulting in 345 firm-year observations. Data are obtained from the financial statements of the firms, which are available on the Internet and the Saudi Securities Market web site (www.tadawul.com.sa). A number of studies, including Al-Malkawi (2008), Osman \& Mohammed (2010), and Al-Ajmi \& Abo Hussain (2011) have used panel data because it provides "more informative data, more variability, less collinearity among the variables, more degrees of freedom and more efficiency" (Baltagi, 2001, p.6). Similar to the argument made by Osman \& Mohammed (2010), and Lin et al. (2014), this study includes both dividend paying firms and non-dividend paying firms to avoid selection bias. Deshmukh (2003) highlights that the exclusion of non-dividend paying firms from any empirical analysis may result in biased and inconsistent estimates of the underlying parameters.

\subsection{Models}

To demonstrate that disclosure quality impacts the dividend payout of a particular firm in the sample, this study utilizes the following models (controlling for firm-specific and industry-level factors).

$$
\begin{gathered}
\operatorname{DIVD}_{i t}=f\left\{\alpha_{i}+\beta \operatorname{DISCLOSE}_{i t-1}+\beta M B_{i t}+\beta \operatorname{CAPEXP}_{i t}+\beta R O E_{i t}+\beta \operatorname{LnTA}_{i t}+\beta \operatorname{LEVERAGE}_{i t}+\beta F C F_{i t}+\right. \\
\left.\beta \operatorname{SINDSTRY}_{i}+\varepsilon_{i}\right\} \\
\mathrm{DIV}_{i t}=\alpha_{i}+\beta D I S C L O S E_{i t-1}+\beta M B_{i t}+\beta \operatorname{CAPEXP}_{i t}+\beta R O E_{i t}+\beta \operatorname{LnTA}_{i t}+\beta \operatorname{LEVERAGE}_{i t}+\beta F C F_{i t}+ \\
\beta I N D U S T R Y_{i}+\varepsilon_{i}
\end{gathered}
$$

Similar to the studies by Al-Ajmi \& Abo Hussain (2011), Lin et al. (2014), and Lin et al. (2016) the dependent variable of the logit regression model in Model 1 is the likelihood of the firm paying dividends (DIVD) and is set to 1 if the firm pays dividend, and 0 otherwise. The logit function is where the probability of DIVD is estimated using the functional form $\pi(\mathrm{x})=\mathrm{e}^{\mathrm{g}(\mathrm{x})} / 1+\mathrm{e}^{\mathrm{g}(\mathrm{x})}$.

Similar to that used by Fama \& French (2002), and Lin et al. (2014), the dependent variable in the panel regression model (Model 2) is the ratio of dividend to total assets (DIV). We also use an alternative measure of dividend to sales ratio, similar to that used by Liu (2002).

Another test of the outcome and substitute models is built on Jensen's (1986) free cash flow theory, which suggests that self-interested managers have the tendency to consume perks and to invest in negative NPV projects to satiate their empire building ambition. We test the agency costs version of the free cash flow theory by regressing the propensity to pay dividends on an interaction term, disclosure quality $\mathrm{x}$ free cash flow (FCF), in addition to our previous set of control variables (Model 3).

$$
\begin{gathered}
\operatorname{DIV}_{i t}=\alpha_{i}+\beta D I S C L O S E_{i t-1}+\beta M B_{i t}+\beta C A P E X P_{i t}+\beta R O E_{i t}+\beta L n T A_{i t}+\beta L E V E R A G E_{i t}+\beta F C F_{i t}+ \\
\beta D I S C L O S E_{i t-1} * \beta F C F_{i t}+\beta I N D U S T R Y_{i}+\varepsilon_{i}
\end{gathered}
$$

Table 1 presents a description of all the relevant dependent, independent and control variables used in the analyses. The independent variable is the disclosure quality measured by a voluntary disclosure checklist. Many prior studies on voluntary disclosure, especially in developing countries, have also used a disclosure checklist (Hossain et al., 1994; Binh, 2012; Al Janadi et al., 2013). The final disclosure checklist developed in this study consists of 78 voluntary items, grouped into seven categories: general corporate information; financial information; forward-looking information; employee information, social responsibility and environmental policy; board structure, responsibilities and evaluation disclosure; audit committee; and risk management. To reduce concerns over endogeneity, we lag disclosure quality by one period (t-1). 
Table 1. Variable Descriptions

\begin{tabular}{|c|c|c|c|}
\hline Variable & Symbol & Expected Sign & Description \\
\hline \multicolumn{4}{|l|}{ Dependent Variables } \\
\hline $\begin{array}{l}\text { Dividend dummy } \\
\text { (logit) }\end{array}$ & DIVD & & $\begin{array}{l}\text { Dummy variable that equals one if the firm pays a } \\
\text { dividend or zero otherwise }\end{array}$ \\
\hline Dividend (panel) & DIV & & Ratio of dividend to total assets \\
\hline \multicolumn{4}{|l|}{ Independent Variable } \\
\hline \multicolumn{4}{|l|}{ Control Variables } \\
\hline $\begin{array}{l}\text { Investment } \\
\text { opportunities }\end{array}$ & MB & - & $\begin{array}{l}\text { Ratio of market value of equity plus the book value of } \\
\text { debt to the book value of assets }\end{array}$ \\
\hline Growth opportunities & CAPEXP & - & Ratio of capital expenditure to total assets \\
\hline Profitability & ROE & + & Ratio of net income to shareholders' equity \\
\hline Firm size & $\operatorname{Ln}(\mathrm{TA})$ & + & Natural logarithm of total assets \\
\hline Leverage & LEV & - & Ratio of total debt to total assets \\
\hline Free cash flow & FCF & + & Ratio of free cash flow to book value of assets \\
\hline Industry dummy & INDUSTRY & & Dummy variables for industrial sectors \\
\hline
\end{tabular}

Based on the existing literature concerning the determinants of dividends (for example: Fama \& French, 2001; Liu, 2002; Lin et al., 2014), we include the following firm-level control variables that have an impact on the dividend payout: (1) investment opportunity (MB), (2) growth opportunity (Capital Expenditure), (3) profitability (ROE), (4) firm size (LnTA), (5) financial leverage (Leverage), and (6) free cash flow (FCF).

Similar to the measurement used by Adam and Goyal (2002), the current study uses the market-to-book-asset ratio (MB) as a proxy for the firm's investment opportunity. Whilst growth opportunity is measured by the ratio of market value of equity plus the book value of debt to the book value of assets. Firms with higher investment opportunities and growth opportunities have a greater cash flow need for future investment and operating activities, and, thus, are expected to have lower dividend payouts. Prior empirical studies (Chang \& Dutta, 2012; Al-Ajmi \& Abo Hussain, 2011) have suggested that firms with higher profitability and larger firms pay out more dividends. Profitability is measured by return on equity (ROE), and firm size (LnTA) is the natural log of total assets. We also control for leverage (Leverage), which is defined as the total debt to total assets in accordance with Lang \& Litzenberger (1989) who consider debt as a corporate governance mechanism for alleviating the potential free cash flow problem. Firms that finance their business activities through borrowing commit themselves to fixed financial charges that would likely result in lower dividend payouts.

Jensen (1986), and Lang \& Litzenberger (1989) suggest that higher dividend payouts make managers waste less FCF on inefficient projects or managerial perks. The study controls for the availability of free cash flow (FCF) by using the ratio of free cash flow to book value of assets. Similar to the measurement used by Lin et al. (2014), FCF is measured by the net cash flow from operating activities net of cash dividend and capital expenditure. To control for possible dummy variations across industries, a dummy of 1 to 13 is used to represent the respective sectors.

\section{Empirical Results}

\subsection{Descriptive Statistics}

Table 2. Descriptive Statistics

\begin{tabular}{ccccccc}
\hline & Obs & Mean & Median & Min & Max & Std Dev \\
\hline DIV & 345 & 0.042 & 0.03 & 0.00 & 0.33 & 0.04 \\
DISCLOSE (\%) & 345 & 44.37 & 41.0 & 11.5 & 68.0 & 25.58 \\
MB & 345 & 2.169 & 1.98 & 0.00 & 12.48 & 7.70 \\
CAPEXP & 345 & 0.07 & 0.04 & 0.01 & 0.49 & 0.18 \\
ROE & 345 & 1.08 & 1.11 & -3.01 & 20.66 & 10.66 \\
LnTA & 345 & 14.67 & 14.55 & 10.70 & 19.64 & 1.62 \\
LEVERAGE & 345 & 0.51 & 0.46 & 0.01 & 2.51 & 0.37 \\
FCF & 345 & 0.04 & 0.02 & -0.91 & 0.45 & 0.06 \\
No of dividend payers & 304 & & & & &
\end{tabular}

Notes. DIV: Ratio of cash dividend to total assets. DISCLOSE: Disclosure score. MB: Ratio of market value of equity plus the book value of debt to the book value of assets. CAPEXP: Ratio of capital expenditure to total assets. ROE: Ratio of net income to shareholders' equity. LnTA: Natural logarithm of total assets. LEVERAGE: Ratio of total debt to total assets. FCF: Ratio of free cash flow to book value of assets.

Table 2 provides the descriptive statistics for the variables in the analysis. The mean and median values for the disclosure score (DISCLOSE) are $44.37 \%$ and $41.0 \%$, respectively. Consistent with prior findings conducted in Saudi Arabia (example AlJanadi et al., 2013; and Alturki, 2014), the low amount of voluntary information 
disclosed in the financial reports among Saudi firms indicates that this type of information is voluntary in nature, and that Saudi capital market authorities do not regulate or enforce voluntary disclosure. Studies by Bhattacharya et al. (2003) and Lang et al. (2006) have also shown that disclosure quality is significantly influenced by country-level reporting standards. The reason for Saudi Arabia having an opaque disclosure environment may be simply because the accounting standards do not call for accounting treatments that transparently reflect the underlying business activity and because management is not willing to overcome these deficiencies by voluntarily disclosing more information.

In Table 3, we further present firm characteristics and the dividend practice of firms is split by voluntary disclosure quality. Using the average score of disclosure quality as the cut-off point, firms with a disclosure quality of $44.37 \%$ and above are characterised as being in the high disclosure quality group, while firms that obtained a disclosure quality of less than $44.37 \%$ are characterised as being in the low disclosure quality group. Most firms in our sample are dividend payers, similar to as reported by previous studies in Saudi Arabia (Bolbol \& Omran, 2004; Osman \& Mohammmed, 2010; Al-Ajmi \& Abo Hussain, 2011). We find that the number of dividend payers (89.2\%) is higher in the low disclosure quality group than in the high disclosure group (83.65\%). The larger dividend (DIV) value (0.33) in the low disclosure quality group provides preliminary support for the substitute hypothesis. That is, corporate insiders in an opaque disclosure environment pay dividend to establish a reputation for the decent treatment of minority shareholders. We also note, however, that these results do not control for other known determinants of dividend payouts.

Table 3. Descriptive Statistics Split By Voluntary Disclosure Score

\begin{tabular}{|c|c|c|}
\hline & $\begin{array}{c}\text { Low Disclosure } \\
\text { (Mean) }\end{array}$ & $\begin{array}{c}\text { High Disclosure } \\
\text { (Mean) }\end{array}$ \\
\hline DIV & 0.33 & 0.15 \\
\hline MB & 1.01 & 2.98 \\
\hline CAPEXP & 0.04 & 0.24 \\
\hline ROE & 1.86 & 6.11 \\
\hline LnTA & 8.67 & 15.05 \\
\hline LEVERAGE & 1.18 & 2.01 \\
\hline FCF & 0.14 & 1.02 \\
\hline$\%$ of dividend payer & $89.2 \%$ & $83.65 \%$ \\
\hline $\mathrm{N}$ (observations) & 241 & 104 \\
\hline
\end{tabular}

Notes. High-disclosure firms are those with a disclosure score of $44.3 \%$ and above, and low disclosure firms are those with a disclosure score of less than $44.3 \%$. DIV: Ratio of cash dividend to total assets. DISCLOSE: Disclosure score. MB: Ratio of market value of equity plus the book value of debt to the book value of assets. CAPEXP: Ratio of capital expenditure to total assets. ROE: Ratio of net income to shareholders' equity. LnTA: Natural logarithm of total assets. LEVERAGE: Ratio of total debt to total assets. FCF: Ratio of free cash flow to book value of assets.

Turning to company operations, the means for profitability (ROE) are 1.86 and 6.11 for the low and high disclosure quality groups, respectively. Similar to the results reported by Osman \& Mohammed (2010), the results in this study show that Saudi firms are highly leveraged through bank loans. Consistent with Brockman \& Ulu (2011), the results in Table 3 suggest that high disclosure firms tend to be larger in size, more profitable and have higher growth opportunities.

\subsection{Multivariate Analysis}

Table 4 reports the regression results using two dividend payout measures. Model 1 uses the logit regression to examine the effect of disclosure quality on the likelihood of dividend payouts. The dependent variable is a dichotomous variable that equals one if the firm pays dividends. Model 2 utilises panel analysis and the random effects model to examine the impact of disclosure quality and dividend payouts for dividend-paying firms only. The dependent variable in Table 4 is the dividend to total assets ratio. Since similar results are obtained when an alternative measure of dividend to sales ratio is used, we only report results for dividend to total assets ratio.

As shown in Model $1 \&$ Model 2, the coefficient of DISCLOSE, which proxies for disclosure quality, is negative and significant suggesting that firms with lower disclosure quality exhibit a higher probability to initiate dividend payment. This evidence is in line with the substitution hypothesis in which managers in an opaque disclosure environment (high agency costs) give higher dividend payouts to establish a reputation for decent treatment of minority shareholders.

The result in our study is similar to that found by Liu (2002) who provides evidence that dividends substitute for external corporate governance. Using a panel of 2,300 firms in 22 economies, Liu (2002) found that 
improvements in information disclosure, insider trading laws, equity market discipline are associated with lower cash dividend ratios and lower sensitivity of dividends to free cash flow. Her results are consistent with the substitute model, which suggests that an improvement in the external corporate governance environment reduces the role of dividends in controlling agency costs, leading to a decrease in dividend.

In contrast, the results found by Adjaoud \& Ben-Amar (2010) show that firms with stronger governance, in particular, board composition and shareholder rights' policy, pay higher dividends. The study by Lin et al. (2014) also supports the outcome hypothesis. Using a sample of Canadian firms, they found that firms with higher disclosure quality exhibit a stronger propensity to pay dividends, and, among dividend payers, they pay larger dividends. Another study that supports the outcome hypothesis is that of Jiraporn et al. (2011).

Further analysis highlights that, in both models, the coefficient of investment opportunities (MB) is positive and significant indicating that firms still pay dividend despite the fact that more cash flow is needed for future investment opportunities. This result is consistent with that found in Luo \& Plumlee (2008), and Aivazian et al. (2003). The coefficient of size (LnTA) is also positive and significant, which is consistent with the argument of Denis \& Osobov (2008), Aivazian et al. (2006), and Osman \& Mohammed (2010) that larger firms have more access to resources for dividend payouts. Similar to the results reported by Aivazian et al. (2006), and Osman \& Mohammed (2010), leverage (LEVERAGE) is negative and significant in both models because debt is also considered as a corporate governance mechanism for alleviating the potential free cash flow problem. Furthermore, the coefficient of free cash flow (FCF) is significantly positive in both models, which indicates that firms with more excess cash have more opportunities to pay dividend, similar to the free cash flow theory (Jensen 1986).

Table 4. The Effect of Voluntary Disclosure Quality and Dividend Payout

Model 1. reports the result of the Logit regression model. Dependent variable (DIVD): Dummy variable that equals one if the firm pays a dividend

$$
\begin{gathered}
\operatorname{DIVD}_{i t}=f\left\{\alpha_{i}+\beta D I S C L O S E_{i t-1}+\beta M B_{i t}+\right. \\
\beta C A P E X P_{i t}+\beta R O E_{i t}+\beta \operatorname{LnTA}_{i t}+\beta L E V E R A G E_{i t}+\beta F C F_{i t}+ \\
\left.\beta I N D U S T R Y_{i}+\varepsilon_{i}\right\}
\end{gathered}
$$

Model 2. reports the result of panel analysis and random effects model. Dependent variable (DIV): Ratio of cash

\begin{tabular}{|c|c|c|}
\hline \multicolumn{3}{|c|}{$\begin{array}{r}\mathrm{DIV}_{i t}=\alpha_{i}+\beta D I S C L O S E_{i t-1}+\beta M B_{i t}+\beta C A P E X P_{i t}+\beta R O E_{i t} \\
\beta I N D U S T R Y_{i}+\varepsilon_{i}\end{array}$} \\
\hline 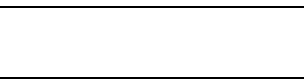 & $\begin{array}{c}\text { Model 1 } \\
\text { (whole sample) }\end{array}$ & $\begin{array}{c}\text { Model 2 } \\
\text { (dividend payers only) }\end{array}$ \\
\hline Constant & $\begin{array}{l}-0.201 * * * \\
(-4.152)\end{array}$ & $\begin{array}{c}-0.198 * * * \\
(-4.256)\end{array}$ \\
\hline DISCLOSE & $\begin{array}{l}-0.035 * * * \\
(-4.472)\end{array}$ & $\begin{array}{c}-0.045 * * * \\
(-4.375)\end{array}$ \\
\hline MB & $\begin{array}{c}0.018 * * * \\
(7.537)\end{array}$ & $\begin{array}{c}0.041 * * * \\
(7.612)\end{array}$ \\
\hline CAPEXP & $\begin{array}{c}-0.030 \\
(-0.694)\end{array}$ & $\begin{array}{c}-0.044 \\
(-0.558)\end{array}$ \\
\hline ROE & $\begin{array}{c}-0.002 \\
(-0.029)\end{array}$ & $\begin{array}{c}-0.010 \\
(-0.041)\end{array}$ \\
\hline LnTA & $\begin{array}{c}0.400 * * * \\
(5.717)\end{array}$ & $\begin{array}{l}0.543^{* *} \\
(2.645)\end{array}$ \\
\hline LEVERAGE & $\begin{array}{c}-0.282 * * * \\
(-4.938)\end{array}$ & $\begin{array}{c}-0.431 * * * \\
(-4.431)\end{array}$ \\
\hline FCF & $\begin{array}{c}0.176^{* * *} \\
(4.121)\end{array}$ & $\begin{array}{c}0.245^{* * * *} \\
(4.164)\end{array}$ \\
\hline INDUSTRY & yes & yes \\
\hline Firm-year observations & 345 & 304 \\
\hline Adjusted $\mathrm{R}^{2}$ & $29 \%$ & $34 \%$ \\
\hline
\end{tabular}
dividends to total assets

Notes. DIV: Ratio of cash dividend to total assets. DIVD: Dummy variable that equals one if the firm pays a dividend. DISCLOSE: Disclosure score. MB: Ratio of market value of equity plus the book value of debt to the book value of assets. CAPEXP: Ratio of capital expenditure to total assets. ROE: Ratio of net income to shareholders' equity. LnTA: Natural logarithm of total assets. LEVERAGE: Ratio of total debt to total assets. FCF: Ratio of free cash flow to book value of assets. The standard errors of the coefficients have been adjusted for autocorrelation and heteroscedasticity using the Newey-West (1987) procedure. 
z-statistics are reported in parentheses. ${ }^{*}, * *, * * *$ denote significance at the $10 \%, 5 \%$ and $1 \%$ level of significance.

Further analysis of Model 1 and Model 2 indicates that growth opportunity (CAPEX) and profitability (ROE) do not seem to have a significant impact on dividends. In contrast to previous literature (Fama \& French, 2001; Luo \& Plumlee, 2008; Al-Ajmi \& Abo Hussain, 2011), the results in this study indicate that firms in Saudi Arabia initiate dividend payouts irrespective of their growth opportunity and level of profitability.

Table 5. Interaction of disclosure quality and free cash flow on dividend payout

Model 3. $\mathrm{DIV}_{i t}=\alpha_{i}+\beta D I S C L O S E_{i t-I}+\beta M B_{i t}+\beta C A P E X P_{i t}+\beta R O E_{i t}+\beta L n T A_{i t}+\beta L E V E R A G E_{i t}+\beta F C F_{i t}+$ $\beta D I S C L O S E_{i t-1} * F C F+\beta$ INDUSTRY $_{i}+\varepsilon_{i}$

\begin{tabular}{lcc}
\hline & Model 3 & $\begin{array}{c}\text { Model 3 } \\
\text { (Dividend payers) }\end{array}$ \\
\hline Constant & (Whole sample) & $-0.112^{* * * *}$ \\
DISCLOSE & $-0.154 * * *$ & $(-4.63)$ \\
& $(-4.143)$ & -0.002 \\
MB & -0.054 & $(-0.871)$ \\
& $(-0.951)$ & $0.041^{* * *}$ \\
CAPEXP & $0.021^{* * *}$ & $(7.052)$ \\
& $(7.231)$ & -0.04 \\
ROE & -0.051 & $(-0.43)$ \\
& $(-0.617)$ & -0.020 \\
LnTA & -0.001 & $(-0.022)$ \\
& $(-0.011)$ & $0.043^{* * *}$ \\
LEVERAGE & $0.413 * * *$ & $(2.44)$ \\
& $(5.144)$ & $-0.131^{* * *}$ \\
FCF & $-0.314 * * *$ & $(-4.70)$ \\
& $(-5.161)$ & $0.125^{* * *}$ \\
DISCLOSE*FCF & $0.218 * * *$ & $(4.99)$ \\
& $(4.217)$ & $-0.101^{* * *}$ \\
INDUSTRY & $-0.2055^{* * *}$ & $(-4.21)$ \\
Firm-year observations & $(-4.913)$ & Yes \\
Adjusted R & yes & 304 \\
\hline
\end{tabular}

Notes. DIV: Ratio of cash dividend to total assets. DISCLOSE: Disclosure score. MB: Ratio of market value of equity plus the book value of debt to the book value of assets. CAPEXP: Ratio of capital expenditure to total assets. ROE: Ratio of net income to shareholders' equity. LnTA: Natural logarithm of total assets. LEVERAGE: Ratio of total debt to total assets. FCF: Ratio of free cash flow to book value of assets. The standard errors of the coefficients have been adjusted for autocorrelation and heteroscedasticity using the Newey-West (1987) procedure.

z-statistics are reported in parentheses. ${ }^{*}, * *, * * *$ denote significance at the $10 \%, 5 \%$ and $1 \%$ level of significance.

Another way of testing the substitute and the outcome models is related to the Jensen (1986) free cash flow theory. Hence, Model 3 in Table 5 extends the equation in Model 2 by examining the interactive variable of voluntary disclosure quality and the free cash flow on its effect on dividend payouts. Column 1 in Table 5 reports the results for the whole sample, while column 2 focuses on dividend payers only. As shown in Table 5 (whole sample and dividend payers only), the coefficient of disclosure quality alone is not significant. However, the interaction of FCF with voluntary disclosure quality provides a negative and significant coefficient, which further supports the substitution hypothesis. The result indicates that the low disclosure quality mainly affects the dividend payout through free cash flow. In addition, the positive correlation between dividend payout and investment opportunities (MB) in Table 5 can also be driven by the substitution hypothesis proposed by La Porta et al. (2002). In an opaque disclosure environment, Saudi firms with excess cash exhibit a larger sensitivity of dividend to investment need to avoid the free cash flow problem advanced by Jensen (1986). As shown in the earlier analysis, the results in Table 5 indicate that firms in Saudi Arabia initiate dividend payouts irrespective of their opportunity for growth and level of profitability.

\section{Summary and Conclusion}

This study examines the outcome and substitute mechanisms to gain a better understanding of how a firm's disclosure environment impacts its dividend payout policy. To date, much of the research has used corporate governance indexes (Bebczuk, 2007; Kowalewski et al.,2008; Chae et al., 2009; Adjaoud \& Ben-Amar, 2010; 
Jiraporn et al., 2011; Bae et al., 2012) or several corporate governance related variables, such as ownership structure, board composition, CEO duality, or board size (Chang \& Dutta, 2012; Abor \& Fiador, 2013), to explain the dividend policy. However, this study focuses on another aspect of the governance issue, disclosure quality, which has received less attention. Second, as most prior studies focused on developed countries like the US, the UK and Canada (Meek \&Gray, 1989; Meek, Roberts and Gray, 1995; DeAngelo et al., 2006; Lin et al., 2014; 2016), it is essential to investigate disclosure quality and its relation with company dividend policy in a developing country like Saudi Arabia. The importance of conducting such studies in a developing economy is that they lack the experience and strong financial infrastructure to address the issues concerning corporate disclosure (Omran, 2009).

We propose that disclosure quality is negatively associated with dividend payment, similar to the substitute hypothesis. As Saudi Arabia is said to be a relatively low investor protection country, we posit that an opaque disclosure environment leads to higher payouts because managers have a stronger incentive to establish their reputation for fair treatment. We further posit that the interaction variable of disclosure quality and free cash flow will result in a significant negative relationship with dividend payout.

Taken together, the results in the study provide evidence that higher dividend payout ratios are observed in Civil Law countries and in countries with lower investor protection. Our analysis supports the substitute hypothesis that firms in Saudi Arabia pay dividends as a mechanism of market self-regulation that can substitute for weak shareholder protection. Managers pay higher dividends, not only to establish a reputation among outside capital suppliers when they operate in an opaque disclosure environment, but also to disgorge excess cash when investment opportunities are abundant in anticipation of free cash flow problems. This result is consistent with the substitute model, that is, weaknesses in the external corporate governance environment increase the role of dividend in controlling agency costs, leading to an increase in dividend payouts.

In addition to contributing to the literature concerning the impact of voluntary disclosure on dividend payout, our findings have policy implications for the current debate on disclosure regulations in Saudi Arabia. As highlighted by Bushman and Landsman (2010), insofar as the regulation of corporate reporting is concerned, one size is unlikely to fit all, given that countries differ in many respects, including political and legal regimes, institutional development, and culture. In fact, commercial sensitivity is often advanced by firms as a reason for resisting demands for increased financial disclosure (Walker, 1988). Our results also suggest that it may not be realistic or optimal to require all firms to provide the same amount of detailed disclosure. Before considering whether the disclosure of certain items should be made mandatory or voluntary among Saudi firms, future research may examine whether voluntary disclosure lowers information asymmetry, mitigates adverse selection risk or reduces financing costs. This aspect of information asymmetry research is very important in the theoretical and empirical literature. Finally, another potential area of research could involve studying how investors view the voluntary information disclosed by companies in the annual report.

Focusing on how voluntary disclosure affects dividend payouts in our research setting has the advantage of minimising ambiguities in the interpretation of the results and increases the power of the tests. A limitation of our paper is that we did not consider all voluntary disclosure items, which we leave to future research.

\section{References}

Abor, J., \& Fiador, V. (2013). Does corporate governance explain dividend policy in Sub-Saharan Africa? International Journal of Law and Management, 55(3), 201-225. https://doi.org/10.1108/17542431311327637

Adam, T., \& Goyal, V., (2002). The investment opportunity set and its proxy variables: Theory and evidence, Working Paper, Hong Kong University of Science \& Technology.

Adjaoud, F., \& Ben-Amar, W. (2010). Corporate governance and dividend policy: Shareholders' protection or expropriation? Journal of Business Finance and Accounting, 37(5/6), 648-667. https://doi.org/10.1111/j.1468-5957.2010.02192.x

Aivazian, V., Booth, L., \& Cleary, S. (2003). Do emerging markets firms follow different dividend policies from the US firms? Journal of Financial Research, 26, 371-387. https://doi.org/10.1111/1475-6803.00064

Aivazian, V., Booth, L., \& Cleary, S. (2006). Dividend smoothing and debt ratings. Journal of Financial and Quantitative Analysis, 41, 439-453. https://doi.org/10.1017/S0022109000002131

Al-Ajmi, J., \& Abo Hussain, H, (2011). Corporate dividends decisions: evidence from Saudi Arabia. The Journal of Risk Finance, 12(1), 41-56. https://doi.org/10.1108/15265941111100067 
Al-habshan, K. S. (2015). Corporate Governance and disclosure practices and protection of shareholders in Saudi Arabia, a thesis submitted for the Degree of Doctor of Philosophy in Law, Brunel University, United Kingdom.

Al-Janadi, Y., Abdul Rahman, R., \& Omar, N., (2013). Corporate Governance Mechanisms and Voluntary Disclosure in Saudi Arabia, Research Journal of Finance and Accounting, 4(4), 25-35.

Al-Malkawi, H. N. Y. (2008). Modelling the dividend policy of GCC banks. Working paper, College of Business Administration, University of Bahrain, Sakhir.

Alturki, K. H. (2014). Voluntary Disclosure by Saudi Companies. Research Journal of Finance and Accounting. 5(20), 77-94.

Alzahrani, Y. A. (2013).The Corporate Governance in Saudi Listed Companies. International Journal of Humanities and Management Sciences (IJHMS), l(4), 84-101

Bae, S. C., Chang, K., \& Kang, E. (2012). Culture, corporate governance, and dividend policy: International evidence. Journal of Financial Research, 35(2), 289-316. https://doi.org/10.1111/j.1475-6803.2012.01318.x

Baltagi, B. (2001). Econometric Analysis of Panel Data. $2^{\text {nd }}$ ed., Wiley, New York, NY.

Bebczuk, R. (2007). Corporate Governance, Ownership, and Dividend Policies in Argentina. In: A. Chong and F. López-de-Silanes, editors. Investor Protection and Corporate Governance: Firm-Level Evidence across Latin America. Stanford, United States: Stanford University Press.

Bhattacharya, U., Daoul, H., \& Welker, M., (2003). The world price of earnings opacity. The Accounting Review, 78, 641-678. https://doi.org/10.2308/accr.2003.78.3.641

Binh, T. Q. (2012). Voluntary Disclosure Information in the Annual Reports of Non Financial Listed Companies: The Case of Vietnam , Journal of Applied Economics and Business Research JAEBR, 2(2), 69-90

Boesso, G., \& Kumar, K. (2007). Drivers of corporate voluntary disclosure - a framework and empirical evidence from Italy and the United States. Accounting, Auditing and Accountability Journal, 20(2), 269-296. https://doi.org/10.1108/09513570710741028

Bolbol, A., \& Omran, M. (2004). Arab Stock Markets and Capital Investment. Working paper, Arab Monetary Fund.

Brockman, P., \& Unlu, E. (2011). Earned/contributed capital, dividend policy and disclosure quality: An international study. Journal of Banking \& Finance, 35, 1610-1625. https://doi.org/10.1016/j.jbankfin.2010.11.014

Bushman, R., \& Landsman, W. R. (2010). The pros and cons of regulating corporate reporting: a critical review of the arguments. Accounting \& Business Research, 40(3), 259-273. https://doi.org/10.1080/00014788.2010.9663400

Chae, J., Kim, S., \& Lee, E. J. (2009). How corporate governance affects payout policy under agency problems and external financing constraints. Journal of Banking and Finance, 33(11), 2093-2101. https://doi.org/10.1016/j.jbankfin.2009.05.003

Chang, B., \& Dutta, S. (2012). Dividends and corporate governance: Canadian evidence. IUP Journal of Applied Finance, 18(4), 5-30.

DeAngelo, H., DeAngelo, L., \& Stulz, R. M. (2006). Dividend policy and the earned/contributed capital mix: A test of the lifecycle theory. Journal of Financial Economics, 81, 227-254. https://doi.org/10.1016/j.jfineco.2005.07.005

Denis, D., \& Osobov, I. (2008). Why do firms pay dividends? International evidence on the determinants of dividend policy. Journal of Financial Economics, 89, 62-82. https://doi.org/10.1016/j.jfineco.2007.06.006

Fama, E. F., \& French, K. R., (2001). Disappearing dividends: Changing firm characteristics or lower propensity to pay. Journal of Financial Economics, 60, 3-43. https://doi.org/10.1016/S0304-405X(01)00038-1

Fama, E., \& French, K. (2002). Testing the trade-off and pecking order predictions about dividends and debt. Review of Financial Studies, 15, 1-33. https://doi.org/10.1093/rfs/15.1.1

Gray, S. J., Meek, G., \& Roberts, C. B. (1995). International capital market pressure and voluntary disclosures by U.S. and U.K. multinationals. Journal of International Financial Management and Accounting, 6, 43-68. https://doi.org/10.1111/j.1467-646X.1995.tb00049.x 
Healy, P. M., \& Palepu, K. G. (2001). Information asymmetry, corporate disclosure, and the capital markets: a review of the empirical disclosure literature. Journal of Accounting and Economics, 31, 405-440. https://doi.org/10.1016/S0165-4101(01)00018-0

Hossain, M., Tan, L. M., \& Adams, M. (1994). Voluntary disclosure in an emerging capital market: Some empirical evidence from companies listed on the Kuala Lumpur Stock Exchange. The International Journal of Accounting, 29, 334-351.

Institute of International Finance. (2006). Comparative Survey of Corporate Governance in the Gulf Cooperation Council - An Investor Perspective. IIF Equity Advisory Group, IIF, Washington DC.

Jensen, M. C. (1986). Agency costs of free cash flow, corporate finance, and takeovers. American Economic Review, 76(2), 323-329.

Jiraporn, P., Kim, J. C., \& Kim, Y. S. (2011). Dividend payouts and corporate governance quality: An empirical investigation. Financial Review, 46(2), 251-279. https://doi.org/10.1111/j.1540-6288.2011.00299.x

Kalcheva, I \& Lins, K., (2007). International Evidence on Cash Holdings and Expected Managerial Agency Problems. Review Finance Studies, 20(4), 1087-1112. https://doi.org/10.1093/rfs/hhm023

Kowalewski, O., Stetsyuk, I., \& Talavera, O. (2008). Does corporate governance determine dividend payouts in Poland? Post-Communist Economies, 20(2), 203-218. https://doi.org/10.1080/14631370802018973

La Porta, R., Lopez-de-Silanes, F., Shleifer, A., \& Vishny, R. W. (2000). Agency problems and dividend policies around the world. Journal of Finance, 55(1), 1-33. https://doi.org/10.1111/0022-1082.00199

Lang, L., \& Litzenberger, R. (1989). Dividend announcements: Cash flow signalling vs free cash flow hypothesis. Journal of Financial Economics, 24, 181-191. https://doi.org/10.1016/0304-405X(89)90077-9

Lang, M., Raedy, J. S., \& Wilson, W. (2006). Earnings management and cross listing: are reconciled earnings comparable to US earnings? Journal of Accounting and Economics, 42, 255-283. https://doi.org/10.1016/j.jacceco.2006.04.005

Lin, D., Kuo, H. C., \& Wang, L. H. (2016). Analysis of the Relationship between Disclosure Quality and Dividend Payouts from the Agency Theory Perspective. Studii Financiare (Financial Studies), Centre of Financial and Monetary Research "Victor Slavescu", 20(1), 6-20.

Lin, D., Kuo, H. C., \& Wang, L.H. (2014). Can Disclosure Quality Explain Dividend Payouts? International Business Research, 7(7), 10-22. https://doi.org/10.5539/ibr.v7n7p10

Liu, W. (2002). Do dividends substitute for the external corporate governance? A cross-country dynamic view. Working paper School of Business, Indiana University.

http://www1.american.edu/academic.depts/ksb/finance_realestate/mrobe/Seminar/WendyLiu.pdf

Luo, M. M., \& Plumlee, M. (2008). Voluntary disclosure and dividend policy. www.fma.org/Reno/Papers/DIVandAIMR_FMA.pdf

Meek, G., \& Gray, S. J. (1989). Globalization of stock markets and foreign listing requirements: Voluntary disclosures by continental European companies listed on the London Stock Exchange. Journal of International Business Studies, 315-336. https://doi.org/10.1057/palgrave.jibs.8490854

Meek, G., Roberts, C., \& Gray, S. (1995). Factors influencing voluntary annual report disclosures by US and UK and continental European multinational corporations. Journal of International Business Studies, 26, 555-572. https://doi.org/10.1057/palgrave.jibs.8490186

Mitton, T. (2004). Corporate governance and dividend policy in emerging markets. Emerging Markets Review, 5(4), 409-426. https://doi.org/10.1016/j.ememar.2004.05.003

Omran, M. (2009). Post-privatization corporate governance and firm performance: The role of private ownership concentration, identity and board composition. Journal of Comparative Economics, 37(4), 658-673. https://doi.org/10.1016/j.jce.2009.02.002

Osman, D., \& Mohammed, E. (2010). Dividend Policy in Saudi Arabia. International Journal of Business and Finance Research, 4(1), 99-113.

Pinkowitz, L., Williamson, R., \& Stulz, R. M. (2007). Cash holdings, dividend policy, and corporate governance: A cross-country analysis. Journal of Applied Corporate Finance, 19(1), 81-87. https://doi.org/10.1111/j.1745-6622.2007.00127.x

Ramcharran, H. (2001). An Empirical Model of Dividend Policy in Emerging Equity Markets. Emerging 
Markets Quarterly, Spring, 39-49.

Walker, M. (1988). The information economics approach to financial reporting. Accounting and Business Research, 18(70), 170-182. https://doi.org/10.1080/00014788.1988.9729362

Wang, K., Sewon, O., \& Claiborne, C. (2008). Determinants and consequences of voluntary disclosure in an emerging market: Evidence from China. Journal of International Accounting, Auditing and Taxation, 17, 14-30. https://doi.org/10.1016/j.intaccaudtax.2008.01.001

Yuen, C. Y., Liu, M., Zhang, X., \& Lu, C., (2009). A case study of voluntary disclosure by Chinese enterprises. Asian Journal of Finance and Accounting, 1(2), 118-145.

\section{Copyrights}

Copyright for this article is retained by the author(s), with first publication rights granted to the journal.

This is an open-access article distributed under the terms and conditions of the Creative Commons Attribution license (http://creativecommons.org/licenses/by/4.0/). 